\title{
The Challenge of Ideological and Political Education in Colleges and Universities under the Network Environment
}

\author{
Xiaoshi $\mathrm{Xu}^{1, \mathrm{a}}$, Le Gao* ${ }^{1, \mathrm{a}}$ \\ ${ }^{1}$ Jilin Agricultural University, Changchun ,China \\ ${ }^{a}$ E-mail: xiaoshitou2001xxs@163.com
}

Keywords: Network communication; ideological and political education; College

\begin{abstract}
Network platform is the most popular way for young college students to chat. The advantage of network platform communication is the increase of information sources, information channels, and current political concerns to help college students to enhance social responsibility. From the negative aspect, the network makes the judgment ability, moral concept and political belief of the college students to be hit. Some college students addicted to Internet leads to the weakening of self-control, and the real life is affected by the virtual world. Ideological education workers in universities should strengthen the construction of the position, and establish a network platform for ideological and political education. Strengthen the media literacy education of college students; strengthen the ranks of security, system security, and improve the system of security system.
\end{abstract}

\section{Introduction}

Popular network communication platform is a platform for information sharing, acquisition and dissemination based on user relationship, such as micro-blog, WeChat and so on. Micro-blog is the user can through the WEB, WAP and other clients to form a personal community; the user can update the information in 140 words, and instant information sharing. WeChat users chat with friends, exchange through send text, photos, audio, video and more people voice intercom. Monthly active users on the messaging apps WeChat and Weixin reached 500m [1].

College students accept new things fast, high level of knowledge, full of the vitality and vitality of the younger generation. WeChat's characteristics precisely meet the needs of College students which are low threshold, low cost, convenience, openness and timeliness [2]. They actively express themselves and show themselves on the Internet through micro-blog and WeChat. Along with the change of these communication methods, the values, thinking mode, behavior pattern and ideology and morality of college students are influenced by them.

\section{Changes of ideological behavior of College Students}

First, increase the source of information. In the "micro era", the positive impact is from the network. Micro-blog and WeChat are highly social communication platforms; each user can receive the latest news and information. Micro-blog and WeChat's in real time message will be higher compared with the traditional media. In the micro era, college students can communicate with friends, to understand the political, financial, cultural, tourism, sports and other information. College students is in a vibrant, harbor the world, ambitious stage of life, platform micro blogging and micro channel for college students interest in public events, the current hot spots, can enhance the social responsibility of college students[3].

Second, meet the personality development and emotional needs of College students. In recent years, university education transforms from elite education to mass education. College students face the practical problems such as job hunting, making friends, they feel the pressure. Micro blog, micro channel for college students provides a platform for emotional communication, and become college students resolve depressed. University Students in this age group is eager to self realization and get respect. They participate in the network, in WeChat and micro-blog to win fans. These 
achievements can bring some sense of achievement, satisfaction and level of spiritual needs of college students.

College Students' ability of judgment, moral values and political beliefs are impacted. WeChat and micro-blog can produce a lot of information every day, of which there are a lot of false information. Some people carefully planned to fabricate rumors, whose purpose is to take revenge or attempt to interfere in implementation of public opinion. Inexperienced college student's participation in the network is sometimes difficult to distinguish between true and false information. Some students may also participate in the spread of rumors. Micro blogging, the letter also appeared all yellow, corrupt, violent news. Some college students pursued the hedonism and money worship under the influence of bad news. Some western countries also took the opportunity to speed up their political system and the value of the concept of output, and wantonly attack China's political system. All these interfere with the political judgment ability and political belief of college students.

Indulge in the network to weaken College Students self-control. Many college students spend most of the time on micro-blog and WeChat. Some students in the classroom use of micro-blog, WeChat, some simply sacrifice sleep time; some college students on micro-blog and WeChat have a strong psychological dependence. They are indifferent to the reality of the world to escape the social and responsibility, and thus the ability of interpersonal communication barriers. More and more college students appear dual personality and psychological disease [4].

\section{Innovation of Ideological and political education in Colleges and Universities}

The network society not only promotes the innovation of Ideological and political education, but also provides the conditions for the innovation of Ideological and political education. WeChat and micro-blog are widely used in various fields of society as a result of the development of information network technology. Some colleges and universities have also opened micro-blog and WeChat public number. Network communication has brought unprecedented opportunities and challenges to the ideological and political education in Colleges and universities.

Enrich the content and form of Ideological and political education in Colleges and Universities. Network communication is a diversified information sharing platform, which provides a large amount of educational resources for the ideological and political education in Colleges and universities. Network platform has information faster, more extensive participation, interaction, etc. The way to convey information can be text, pictures, audio, video, etc. Educators can use the Internet to overcome the shortcomings of the education process, such as monotonous, empty and boring and so on.

Improve the pertinence and effectiveness of Ideological and political education in Colleges and Universities. Ideological and political education workers in Colleges and universities can be "zero distance" access to college students in a timely manner and grasp the ideological trends of College students. They can understand the psychological needs of college students, the level of knowledge and learning status. This can improve the pertinence and effectiveness of education. Ideological and political education is a system which needs the joint efforts of school, family and society.

Construct a new platform of Ideological and political education in Colleges and Universities. College students can learn knowledge and exchange feelings on micro-blog and WeChat which is more convenient for people to share their resources. Ideological and political education in Colleges and universities can take the network platform as an extension of classroom teaching. Deepening the exchange between teachers and students can improve the level of Ideological and political education and enhance the effectiveness of education [5]. The network will become the focus of the majority of college education research topics.

\section{Countermeasures of political education in Colleges and Universities}

First, strengthen the network construction. Schools should launch micro-blog and WeChat platform. For example, the registry can release the course information and notice on the network platform; library can lecture information published on the network platform, library and information; 
employment center can release employment guidance and employment information; the performance center can be issued ticket information, inform performances. Ideological and political education workers in Colleges and universities can also use the Internet to communicate with students. Ideological and political educators in Colleges and universities should actively convey the correct and positive information, so that micro-blog and WeChat will become the platform for education and learning to expand the influence of Ideological and political education.

Second, strengthen college students' Media Literacy Education. Media literacy is the ability of people to obtain, analyze, evaluate and disseminate information of various forms, which is the function and significance of people's correct judgment and media information. University Students' media literacy is not innate, but also relies on education. Media literacy education aims to help students screening, selection and reflection of the media information to improve college students are faced with all kinds of complicated information selection ability, understanding ability and evaluating ability, creative ability and comprehensive ability. The focus of media literacy education in Colleges and universities is to help students build a healthy world outlook, outlook on life and values.

Third, Strengthen the Teaching Staff Construction and improve the security system. In the network environment, the ideological and political education in Colleges and universities need the teams of teachers with the strong political quality, rich work experience and a higher quality of network information quality. The teams of workers should be involved in the exchange of students of micro-blog and WeChat who have the ability to extract and process information to ensure the advanced nature of the work of Ideological and political education and efficiency. Colleges and universities should also develop micro-blog, WeChat's management norms to regulate the network behavior of College students. Restrict the use of micro-blog, WeChat to enhance college students' self-control and immunity to avoid college students addicted to the network. Establish a harmonious university micro-blog, WeChat environment and atmosphere. These students as "opinion leaders" should guide public opinion toward the direction that is conducive to the development of college students.

\section{Conclusion}

It can be seen that the development of the ideological and political education also need material guarantee to promote ideological and political education work and promote the work of Ideological and political education in Colleges and universities. Ideological education workers in universities should strengthen the construction of the position, and establish a network platform for ideological and political education.

\section{Acknowledgement}

Study on the integration of traditional culture into the ideological and political issues, Project relating to the Twelfth Five Year Planning Project for Education Science in Jilin Province (No. ZD14050)

\section{Reference}

[1]Wang C. A Study of Ideological and Political Education Method of College Students Based on WeChat[J]. Theory \& Practice of Education, 2014.

[2]Guo H S, Han F, Amp S O, et al. Application of WeChat in the Ideological and Political Education for College Students[J]. Yinshan Academic Journal, 2014.

[3]Wang R, Zhao W, Ran R. Research on the Ideological and Political Education of College Students Based on the Mobile Phone Environment[J]. International Journal of Digital Content Technology \& Its Applications, 2013, 7(7):112-119. 
[4] Liu Y. The Research on Ideological and Political Education Method Based on College Student Innovation Ability in Information Environment[C]// Advances in Computer Science, Environment, Ecoinformatics, and Education - International Conference, Csee 2011, Wuhan, China, August 21-22, 2011, Proceedings. 2011:392-397.

[5]Pan Y, Tu K. Method Innovation of Undergraduate Ideological and Political Education Based on Network Environment[J]. Procedia Engineering, 2011, 15:2752-2756. 